\title{
CEO Succession, Investor Expectations, and Real Earnings Management
}

\author{
Chaur-Shiuh Young \\ Department of Accountancy and Graduate Institute of Finance \& Banking \\ National Cheng Kung University \\ No.1 University Rd., Tainan City 701, Taiwan \\ Tel: 886-6-275-7575 \#53445_E-mail: actycs@mail.ncku.edu.tw \\ Yueh-Ju Lin (corresponding author) \\ Department of Accounting, Kainan University \\ No. 1 Kainan Rd., Luzhu, Taoyuan 33857, Taiwan \\ Tel: 886-3-341-2500\#1661Ｅ-mail: judylin@mail.knu.edu.tw
}

Fei-Liang Chien

Department of Accounting, Kainan University

No. 1 Kainan Rd., Luzhu, Taoyuan 33857, Taiwan

Tel: 886-3-341-2500\#4901Ｅ-mail: acctvera@gmail.com

Chia-Hui Chen

Dept. of Accounting, National Dong Hwa University

No.1 Sec.2, Da Hsueh Rd., Shoufeng, Hualien, 97401

Tel: 886-3-863-3088Ｅ-mail:chchen@mail.ndhu.edu.tw

Received: Sep. 8, 2015 Accepted: Oct. 11, $2015 \quad$ Published: December 1, 2015

doi:10.5296/ajfa.v7i2.8318 URL: http://dx.doi.org/10.5296/ajfa.v7i2.8318 


\begin{abstract}
Recently, U.S. firms are switching CEO at the fastest pace and these events often cause severe stock market volatility on the uncertainty of the firm's future performance. This study investigates whether inverse market reaction on CEO succession will induce earnings management of new CEOs in order to protect their reputational and career prospects. From a sample of 2,418 firm-years during the post-SOX period of 2003 to 2012 by applying the regression analysis, we investigate two associations of real earnings management (REM) with CEO successions and with its market reaction respectively. Our results suggest new CEOs are more careful when manipulate earnings through REM activities. However, REM is negatively associated with market expectations on CEO successions, implying new CEOs may utilize REM to reverse the first bad impressions held by investors. We provide a new perspective with regard to market reactions to CEO successions, by examining how and why new CEOs may choose to manipulate earnings.
\end{abstract}

Keywords: CEO succession, CEO impression management, Market reaction, Abnormal return, Real operating activities manipulation, Earnings management

JEL classification: G14, M12, M40, M41 


\section{Introduction}

On October 8, 2011 The Wall Street Journal stated that the average tenure of a Fortune 500 CEO was 10 years in 2000, eight years in 2010, but only 4.6 years in 2011 . When a firm changes its chief executive officer (CEO), who is mainly responsible for the firm's operating strategies, investment decisions, and resources allocations, thus the level of uncertainty is raised. Prior studies show that changing the CEO can significantly impact the stock price and operations of a firm, due to the unknown aspects of "human capital" and the signalling of uncertainty with regard to the company's strategies (Furtado and Karan 1990; Clayton et al. 2005).The issue of CEO successions, and their related effects, is thus an issue that deserves more research.

A series of financial accounting studies that examine the relation between CEO succession and the quality of financial statements find that new CEOs may engage in earnings management through manipulation discretionary accruals. Based on the idea of "taking a big bath", these works find that new CEOs tend to lower earnings in the transition year, as these can be blamed on the departing CEOs, and then take advantage of accruals reversals to improve performance in the next year, thus enhancing their own reputations (e.g. Pourciau 1993; Godfrey et al. 2003). A survey carried out by Graham et al. (2005) shows that the goal of establishing and maintaining a good reputation may significantly affect the financial reporting decisions that CEOs make. Furthermore based on the "rent extraction" perspective, Francis et al. (2008) find that highly reputed CEOs have stronger motivations to manipulate earnings in order to maintain their professional images, which may result in lower quality reporting of earnings.

In contrast, Ali and Zhang (2013) suggest that as CEO tenure becomes longer, CEOs prefer to recognize negative news in a timely manner and to reduce the amount of discretionary accruals in order to protect their reputation. Cao et al. (2012), extending the concept of reputation to the entire company, show that reputational concerns can motivate highly reputed firms to maintain good financial reporting quality. Overall, although tenure, career reputation, or the idea of taking big bath may be the reasons to impact new CEOs earnings management decisions, undoubtedly, CEOs on their successions may possess the motivation of earnings management.

However, these studies only focus on accruals management (hereafter AEM), and neglect real earnings management (hereafter REM). REM means managing a firm's real operating activities to meet or beat earnings benchmarks, and this approach is more likely to impact the firm's cash flows and future performance than the use of AEM to achieve this. Due to the high litigation risk in the post-SOX (Sarbanes-Oxley Act) period, managers now use REM more often than AEM to manipulate earnings (Graham et al. 2005; Cohen et al. 2008). Our first research purpose is thus to explore whether firms with CEO successions have more incentives to engage in REM than those without CEO successions.

Prior studies indicate that a CEO's public image is established based on market perceptions of their abilities (e.g. Holmstrom 1999; Milbourn 2003). Any unexpected equity volatility due to new CEO may represent investors' perceptions or valuations of the new CEO's abilities. A positive market perception (reaction) can motivate managers to manage earnings to match investors' expectations, so as to build or retain their reputations and career prospects. However, the incoming CEOs if face with negative market reactions have stronger motivations to prove the market their capabilities through aggressive earnings management to 
reverse investors' negative beliefs (Clayton et al. 2005). It is thus an empirical issue as to how market expectations affect a new CEO's earnings management behaviors.

This work matches one non-succession observation for each succession observation and finds that compared to non-succession firms, CEO succession firms are negatively related with REM, indicating the new CEO is likely to carefully use REM as a way to enhance earnings. However, we also find that when new CEOs are faced with negative cumulative abnormal returns (CARs), they are more likely to engage in REM than those with positive CARs, since they are under more pressure to reverse the negative perceptions that the market has of them. These findings are also supported by the additional test of change models, which is a way to exclude the issues of inherent earnings management and self-selection bias from our results.

Our evidence offers varied insights from previous studies by proving the increasing market volatility can influence the new CEO's accounting policies in order to protect their reputations and job prospects. We offer evidence with regard to how the market's perceptions of new CEOs' capabilities affect their real earnings management behavior.

The rest of this paper is organized as follows. Section 2 presents a review of the literature and hypotheses development, while Section 3 provides our research design and empirical models. Section 4 presents the empirical results of this work, and Section 5 then gives the conclusions.

\section{Literature Reviews and Hypotheses Development}

\subsection{Earnings Management and CEO Succession}

The prior literature indicates that new CEOs have greater incentives to manipulate discretionary accruals, since they face pressure to convince the board and investors that they are able to improve future earnings. According to Davidson III et al. (2004), the first impression new CEOs establish can have significant effects on their career prospects and firms' future performance. Ali and Zhang (2013) note that a short tenured CEO may engage in aggressive financial reporting choices in order to establish a good reputation at an early stage of their career. Therefore, CEOs have an incentive to inflate reported earnings at the beginning of their tenure. Similarly, Francis et al. (2008) and Seybert (2010) provide empirical and experimental evidence to support the view that CEOs' reputational concerns significantly affect their financial reporting decisions.

On the other hand, most prior studies support the idea of "taking a big bath", that new CEOs tend to decrease earnings in the year of their succession to impute the bad performance to the pervious managers and to lower the benchmark for performance in the subsequent year. Then, the new CEO may be able to significantly improve results, and thus impress stakeholders (Pourciau 1993; Godfrey et al. 2003). Taken together, these results indicate that CEO succession may impact financial reporting quality, although in exactly what ways remains an open question.

\subsection{Management Behavior with regard to Manipulating Real Operating Activities}

According to Healy and Wahlen (1999), Roychowdhury (2006) defines it as "departures from normal operational practices, motivated by managers' desire to mislead at least some stakeholders into believing certain financial reporting goals have been met in the normal course of operations." In short, REM is when CEOs manipulate real operating activities to meet short-term earnings targets. 
Managers may engage in earnings management to meet benchmarks in an effort to enhance the firm's credibility and reputation with stakeholders (Burgstahler and Dichev 1997; Bartov et al. 2002). The survey in Graham et al. (2005) finds that 74.1 percent of managers try to meet earnings benchmarks to provide evidence of future growth prospects. Managers tend to engage more of REM than AEM because of the fear of accounting fraud stigma attached after SOX or litigation associated with AEM (Cohen and Zarowin 2010; Cohen et al 2008; Gunny 2010; Roychowdhury 2006; Taylor and Xu 2010; Zang 2012).

As managers prefer applying REM to manage short-term earnings, which is harder to be detected (Cohen et al. 2008; Cohen and Zarowin 2010; Zang 2012), REM may influence a firm's cash flows and future performance by altering operating activities. However, concerning reputation and career prospective, whether the CEO successor manages earnings through altering real operation activities remains uncertain. Therefore, we test the following non-directional hypothesis, stated in its null form, to examine this issue:

\section{H1: CEO successions are not associated with real earnings management.}

\subsection{Market Reactions to CEO Successions}

A market reaction means a news or a relevant economic release which may induce a strong directional move in stock markets. Through these reactions, the investor's perception of that event will be observed. Prior studies have documented the relationship between market reactions and CEO changes. For example, Beatty and Zajac (1987) suggest that CEO turnover leads to uncertainties about firm strategy, which can have adverse impacts on investors' perceptions of the company. Huson et al. (2004) and Demerjian et al. (2011) find positive market reactions when a poorly performing CEO is replaced by an outside manager, since investors feel that this may improve future performance. Similarly, Holmstrom (1999) and Milbourn (2003) state that a CEO's reputation is based on the market perceptions of their abilities. That is, a significant reaction to CEO succession may signal (1) expectation with regard to the firm's future operations and (2) concerns about the successor's abilities (Clayton et al. 2005).

Moreover, one question that arises in this context is whether the market reaction to a new CEO induces the incentive of earnings management by manipulating real operating activities of the new manager? A survey in Graham et al. (2005) indicates that CEOs are concerned about stock price losses, which may significantly damage both their reputations and job prospects. The survey further states that managers often choose to sacrifice the long term economic value of their firms to avoid more severe firm value damaged by market reactions to missing the earnings expectations of analysts and investors. Some studies also document that when managers face increased capital market pressure, they may sacrifice the long term value of a firm to achieve short term earnings benchmarks (Bhojrai and Libby 2005; Zhao et al. 2012).

In this study, we postulate that when positive market reactions occur in response to CEO succession, investors judge the new CEO is competent. Thus, in order to protect their reputations, these welcomed CEOs by market tend not to apply REM which may damage a firm's future operating performance. In contrast, when negative market reactions occur in 
response to CEO succession, the new CEO is more likely to aggressively enhance earnings in order to immediately rebuild investors' confidence (Clayton et al. 2005). That is, CEO successors suffer negative market reactions may engage in higher level of REM. Accordingly, the second hypothesis is thus as follows:

H2: The degree of real earnings management is more pronounced for successor CEOs who face greater pressure with regard to satisfying the expectation of investors.

\section{Methodology and Data}

\subsection{Regression Model}

To investigate the impact of hiring a new CEO on a firm's use of REM, we match one non-succession observation for each succession observation based on the same industry, same year, and nearest total assets. Equation (1) is used to test hypothesis one, based on Roychowdhury (2006) and Gunny (2010).

$$
\begin{aligned}
R E M_{i, t}=\beta_{0}+\beta_{1} S U C_{i, t}+ & \beta_{2} D A_{i, t}+\beta_{3} L N A T_{i, t}+\beta_{4} M B_{i, t}+\beta_{5} R O A_{i, t}+\beta_{6} L E V_{i, t} \\
& +\beta_{7} B I G 4_{i, t}+\beta_{8} L_{I T I G A T I O N}+\varepsilon_{i, t}
\end{aligned}
$$

Second, we use succession observations to detect how market reactions to CEO successions impact the degree of REM. The hypothesis two is examined by Equation (2) which is shown as follows.

$$
\begin{array}{r}
R E M_{i, t}=\gamma_{0}+\gamma_{1} C A R_{i, t}+\gamma_{2} D A_{i, t}+\gamma_{3} L N A T_{i, t}+\gamma_{4} M_{i, t}+\gamma_{5} R O A_{i, t}+\gamma_{6} L E V_{i, t} \\
+\gamma_{7} B I G 4_{i, t}+\gamma_{8} \text { IITIGATION }_{i, t}+\mu_{i, t}
\end{array}
$$

The next section presents the definitions of the variables and their predicted signs.

\subsection{Variable Definitions}

\subsubsection{Dependent Variables: Proxies for Real Earnings Management (REM)}

Following Dechow et al. (1998) and Roychowdhury (2006), we use abnormal cash flows from operations (AB_CFO), abnormal production costs (AB_PROD), and abnormal discretionary expenditures (AB_DISEXP) as measurements of REM. First, lower AB_CFO is achieved through sales manipulation, by offering sales discounts or lenient credit terms to boost sales and temporary increase earnings. Second, engaging in overproduction, a lower of operating cash flow and cost of goods sold (COGS) is implied. Third, reducing discretionary expenditures in sales and administration, $R \& D$ and advertisement can avoid losses and inflate earnings, and when paid in cash, operating cash outflows is lowered.

When firms manage earnings upward, it is more likely to result in abnormally low cash flows from operations and discretionary expenditures, and abnormally high production costs. The normal level of CFO is estimated through Equation (3) based on the model, which is a linear function of sales and changes in sales, estimated for each year and industry through a cross-sectional regression. Note that AB_CFO is multiplied by -1 , so that a higher value indicates a higher degree of upward sales manipulation. 


$$
\frac{C F O_{i, t}}{A_{i, t-1}}=\alpha_{0}+\alpha_{1} \frac{1}{A_{i, t-1}}+\alpha_{2} \frac{\text { Sales }_{i, t}}{A_{i, t-1}}+\alpha_{3} \frac{\text { s. }_{3} \text { ales }_{i, t}}{A_{i, t-1}}+\varepsilon_{i, t}
$$

where for fiscal year $t$ and firm $\mathrm{i}, \mathrm{CFO}_{\mathrm{i}, \mathrm{t}}$ is cash flow from operations in year $\mathrm{t} ; \mathrm{A}_{\mathrm{i}, \mathrm{t}-1}$ is total assets at the beginning of year $t$; Sales ${ }_{i, t}$ is the sales during year $t$; and $\Delta$ Sales $_{i, t}$ is change in sales in year $\mathrm{t}$, defined as Sales $_{\mathrm{i}, \mathrm{t}}-$ Sales $_{\mathrm{i}, \mathrm{t}-\mathrm{1}}$.

Second, we define overproduction as AB_PROD, estimated by subtracting the normal level of production costs from the actual production costs. The normal level of production costs (PROD), as shown in Equation (4), is the sum of COGS and change in inventory ( $\triangle \mathrm{INV})$ during the year. COGS is a linear function of the contemporaneous sales, as shown in Equation (5), and the change in inventory is also a linear function of the contemporaneous and lagged changes in sales, as shown in Equation (6).

$$
\begin{aligned}
\frac{\operatorname{PROD}_{i, t}}{A_{i, t-1}}= & \operatorname{COGS}_{i, t}+\Delta I N V_{i, t} \\
& =\alpha_{0}+\alpha_{1} \frac{1}{A_{i, t-1}}+\alpha_{2} \frac{\text { Sales }_{i, t}}{A_{i, t-1}}+\alpha_{3} \frac{\Delta \text { Sales }_{i, t}}{A_{i, t-1}}+\alpha_{4} \frac{\Delta \text { Sales }_{i, t-1}}{A_{i, t-1}}+\varepsilon_{i, t}
\end{aligned}
$$

$$
\text { given } \frac{\operatorname{COGS}_{i, t}}{A_{i, t-1}}=\alpha_{0}+\alpha_{1} \frac{1}{A_{i, t-1}}+\alpha_{2} \frac{\text { Sales }_{i, t}}{A_{i, t-1}}+\varepsilon_{i, t}
$$

$$
\text { and } \quad \frac{\Delta I N V_{i, t}}{A_{i, t-1}}=\alpha_{0}+\alpha_{1} \frac{1}{A_{i, t-1}}+\alpha_{2} \frac{\Delta \text { Sales }_{i, t}}{A_{i, t-1}}+\alpha_{3} \frac{\Delta \text { Sales }_{i, t-1}}{A_{i, t-1}}+\varepsilon_{i, t}
$$

where for fiscal year $\mathrm{t}$ and firm $\mathrm{i}, \mathrm{PROD}_{\mathrm{i}, \mathrm{t}}$ is the production costs in period $\mathrm{t}$; defined as the sum of COGS and the change in inventory; $\mathrm{COGS}_{\mathrm{i}, \mathrm{t}}$ is costs of goods sold during year $\mathrm{t}$; $\Delta \mathrm{INV}_{\mathrm{i}, \mathrm{t}}$ is the change in inventory in year $\mathrm{t}$; and $\Delta \mathrm{Sales}_{\mathrm{i}, \mathrm{t}}$ is change in sales in year $\mathrm{t}$.

The third form of REM is AB_DISEXP, which is estimated by subtracting the normal level of discretionary expenditures (DISEXP) from the actual ones. The normal level of discretionary expenditures is predicted through Equation (7), which is a linear function of lagged sales, estimated for each year and industry through cross-sectional regression. Abnormally low discretionary expenditures indicate a reduction in this spending. We multiply AB_DISEXP by -1 , so that a higher value represents a greater reduction in discretionary expenditures.

$$
\frac{\operatorname{DISEXP}_{i, t}}{A_{i, t-1}}=\alpha_{0}+\alpha_{1} \frac{1}{A_{i, t-1}}+\alpha_{2} \frac{\text { Sales }_{i, t-1}}{A_{i, t-1}}+\varepsilon_{i, t}
$$


where for fiscal year $\mathrm{t}$ and firm $\mathrm{i}, \operatorname{DISEXP}_{\mathrm{i}, \mathrm{t}}$ is the discretionary expenditures in period $\mathrm{t}$; defined as the sum of advertising, R\&D, and selling, general and administrative (SG\&A) expenses; and Sales $_{\mathrm{i}, \mathrm{t}-1}$ is sales in the beginning of year $\mathrm{t}$.

Finally, in order to capture the effects of REM through all these three variables in a comprehensive measure, we compute an aggregated variable (SUM_REM) representing the sum of the standardized variables AB_CFO, AB_PROD, and AB_DISEXP. And the higher value of SUM_REM represents relatively higher level of REM.

\subsubsection{Independent Variables}

As Equation (1) is applied to test hypothesis one, we use an indicator variable (SUC) to proxy CEO succession. SUC equals 1 if the firm has experienced a CEO succession in year $t$, and 0 otherwise. According to the inference of hypothesis one, we do not state any predicted signs with regard to the associations between CEO succession and REM.

As prior studies indicate that a CEO's reputation is established by market perceptions of their abilities (e.g. Holmstrom 1999; Milbourn 2003), we assume that market reaction to a CEO succession reflects investor perception of the reputation of the new manager. Referring to Brown and Warner (1980), we use the market adjusted return to measure the market reaction by CAR for a three-day window period, starting one day prior to the succession. The proxy we use is the simple sum of the abnormal return, given by the difference between the firm's return and that of a market portfolio, over the three-day window $(-1,1)$, since Beaver (1968) documents that most market reactions occur during this period.

For the test of hypothesis two in Equation (2), we predict that the market reaction to the succession is an explanatory variable that will negatively affect the level of $\operatorname{REM}\left(\gamma_{1}<0\right)$. That is, the more market pressure (negative market reaction) the new CEO suffers, the grater the incentive to carry out REM. Furthermore, we divide the CARs into two groups, positive and negative, and then we apply the Wald Coefficient Test to examine the differences between these. When we estimate Equation (2) using these two groups of CARs, we use the absolute value of CARs (CAR*) to integrate the predicted direction, and thus a positive relation between absolute value of CARs and REM is predicted, specifically in the negative CARs group. If the coefficient of CAR in the group with negative CARs $(\mathrm{CAR}<0)$ is significantly greater than that in the group with positive CARs $(\mathrm{CAR}>0)$, then hypothesis two is supported.

\subsubsection{Control Variables}

As prior studies have demonstrated that firms generally manipulate earnings using REM and AEM simultaneously (Roychowdhury 2006; Cohen and Zarowin 2010; Gunny 2010; Zang 2012), we incorporate discretionary accruals (DA) to represent AEM in the regression and predict a positive relation between REM and AEM. To estimate AEM, a performance-matched modified-Jones model (1991) is applied and ROA is also included as the application of accruals to manage earnings is affected by firm performance (Kothari et al 2005) 
Because of the systematic variations in growth opportunities and size effects on REM (Roychowdhury 2006), both market-to-book value ratio (MB) and firm size (LNAT) estimated by the logarithm of total assets at the beginning of the year are included in the model. In addition, ROA, measured as income before extraordinary items scaled by lagged total assets, is also controlled in our regression (e.g. Roychowdhury 2006; Gunny 2010; Zang 2012). We do not predict signs on the associations between these three variables and REM, as in Roychowdhury (2006). We also control for the leverage (LEV) since a high ratio of debt to equity generally implied earnings manipulation (Watt and Zimmerman 1986). LEV is the ratio of total liabilities to total assets.

Finally, BIG4 is a dummy variable that equals 1 if the firm engaged one of the largest four audit firms, and 0 otherwise. Firms audited by big four auditors may choose REM instead of AEM when managing earnings, since after SOX, AEM is easier to detect and relatively costly than REM (Chi et al. 2011; Zang 2012). Firms in high litigation risk industries (LITIGATION) are also more likely to be noticed and detected by the public and regulators if manage earnings through AEM (Cohen and Zarowin 2010; Zang 2012). LITIGATION is a dummy variable that equals 1 if the firm is in SIC codes 2833-2836, 3570-3577, 3600-3674, 7371-7379, and 8731-8734, and 0 otherwise.

\subsection{Data and Sample Selection}

We collect the CEO changes, financial and stock price related data from the Execucomp, Compustat, and CRSP databases, respectively. The initial sample from Execucomp with CEO changes is 2,418 firm-years for the period of 2003 to 2012. The sampling period starts in 2003 to avoid the influence of SOX, based on Cohen et al. (2008), who suggest that firms have engaged in more REM after SOX. We exclude financial firms (SIC codes 6000 to 6500), firms in regulated industries (SIC does 4400 to 5000), and public administration and other firms (SIC codes 9000 to 10000), because the REM models applied in this work are not suitable for these industries. After deleting observations with missing data and outliers whose absolute value of studentized residual from the regression is greater than two, we match one non-succession observation for each succession observation based on the same industry, year, and nearest total assets, leading to a final sample of 2,339 firm-years for testing hypothesis one. The sample used to test hypothesis two is based on the initial 1,241 firm-year sample before excluding outliers for testing hypothesis one, and after eliminating outliers (using the same method as with $\mathrm{H} 1$ ) we obtain a final sample of 1,178 firm-years.

\section{Empirical Analysis}

\subsection{Descriptive Statistics}

Table 1 provides the descriptive statistics of the research variables used in the analysis. Compared to non-succession firms, firms in the succession sample tend to have significantly lower means and medians for most REM proxies. These results show that firms with new CEOs are less likely to engage in REM than those that do no change their CEOs. The mean (median) of the CAR at a three-day window around the CEO succession is 0.0015 (0.0003), indicating that on average the market believes that the new $\mathrm{CEO}$ will be able to improve the 
firm's performance. The succession group has a lower mean and median in the performance measure (ROA) than the non-succession control group. The significantly lower performance in CEO succession firms indicates that firms with poor performance tend to replace CEOs in order to turn around current operations. We do not find any significant differences between the succession and non-succession samples with regard to the other variables, indicating that the sample matching process is valid and there is no significant difference between the testing and control groups. In Table 1, since we examine the differences between the variables for the testing and control groups, we use the sample for $\mathrm{H} 1$ to present the descriptive statistics. There are no significant differences in the results when we use the sample $(1,178)$ for $\mathrm{H} 2$ (untabulated).

Table 1. Descriptive statistics

\begin{tabular}{|c|c|c|c|c|c|c|c|c|}
\hline \multirow[b]{2}{*}{ Variables $^{2}$} & \multicolumn{3}{|c|}{$\begin{array}{l}\text { Succession Sample } \\
(\mathrm{N}=1,166)\end{array}$} & \multicolumn{3}{|c|}{$\begin{array}{c}\text { Non-Succession Sample } \\
(\mathrm{N}=1,173)\end{array}$} & \multicolumn{2}{|c|}{ Difference Tests } \\
\hline & Mean & Median & $\begin{array}{l}\text { Standard } \\
\text { Deviation }\end{array}$ & Mean & Median & $\begin{array}{l}\text { Standard } \\
\text { Deviation }\end{array}$ & $\begin{array}{c}\text { Mean } \\
t \text {-statistics }\end{array}$ & $\begin{array}{c}\text { Median } \\
z \text {-statistics }\end{array}$ \\
\hline SUM_REM & -0.0309 & -0.0066 & 0.3053 & 0.0177 & 0.0201 & 0.3076 & $-3.83 * * *$ & $-3.46 * * *$ \\
\hline $\mathrm{AB} \_\mathrm{CFO}^{1}$ & -0.0403 & -0.0349 & 0.0912 & -0.0412 & -0.0371 & 0.0895 & 0.25 & 0.19 \\
\hline AB_PROD & -0.0343 & -0.0282 & 0.1488 & -0.0124 & -0.0106 & 0.1519 & $-3.52 * * *$ & $-3.21 * * *$ \\
\hline AB_DISEXP ${ }^{1}$ & 0.0437 & 0.0535 & 0.1681 & 0.0713 & 0.0775 & 0.1633 & $-4.04 * * *$ & $-3.90 * * *$ \\
\hline DA & -0.0169 & -0.0142 & 0.0535 & -0.0094 & -0.0081 & 0.0549 & $-3.37 * * *$ & $-3.40 * * *$ \\
\hline CAR & 0.0015 & 0.0003 & 0.0599 & - & - & - & - & - \\
\hline LNAT & 7.2447 & 7.1144 & 1.6687 & 7.2448 & 7.1263 & 1.6802 & -0.00 & -0.11 \\
\hline MB & 2.9688 & 2.1113 & 2.8020 & 2.8625 & 2.0769 & 2.6242 & 0.95 & 0.73 \\
\hline $\mathrm{ROA}$ & 0.0247 & 0.0446 & 0.1242 & 0.0393 & 0.0504 & 0.1057 & $-3.06 * * *$ & $-2.19 * *$ \\
\hline LEV & 0.4849 & 0.4868 & 0.1982 & 0.4852 & 0.4897 & 0.2046 & -0.04 & -0.20 \\
\hline BIG4 & 0.9160 & 1.0000 & 0.2776 & 0.8977 & 1.0000 & 0.3032 & 1.52 & 1.52 \\
\hline LITIGATION & 0.2702 & 0.0000 & 0.4442 & 0.2472 & 0.0000 & 0.4316 & 1.27 & 1.27 \\
\hline \multicolumn{9}{|c|}{$\begin{array}{l}{ }^{1} \text { We multiply the abnormal levels of cash flow from operations and the abnormal levels of discretionary expenditures by }-1 \text {, so } \\
\text { that the higher values of these two variables represent higher REM. }{ }^{2} \text { SUM_REM: the aggregation of AB_CFO, AB_PROD, } \\
\text { and AB_DISEXP; AB_CFO: the abnormal level of cash flow from operations; AB_PROD: the abnormal level of production } \\
\text { costs; AB_DISEXP: the abnormal level of discretionary expenditures; SUC: a dummy variable that equals } 1 \text { indicating CEO } \\
\text { succession, and } 0 \text { otherwise; CAR: cumulative abnormal return over the three-day window (-1,1); DA: the discretionary } \\
\text { accruals estimated using the "performance-matched" modified-Jones model; MB: the ratio of market value of equity to book } \\
\text { value of equity; LNAT: the logarithm of the market value of equity at the beginning of the year; ROA: income before } \\
\text { extraordinary items scaled by lagged total assets; LEV: the ratio of total liabilities to total assets; BIG4: a dummy variable that } \\
\text { equals } 1 \text { if the firm engaged one of the largest four audit firms, and } 0 \text { otherwise; LITIGATION: a dummy variable that equals } 1 \\
\text { if the firm is in SIC codes } 2833-2836,3570-3577,3600-3674,7371-7379 \text {, and } 8731-8734 \text {, and } 0 \text { otherwise. }\end{array}$} \\
\hline
\end{tabular}

\subsection{Multivariate Results}

\subsubsection{Results for the Relation between Real Earnings Management and CEO successions}

Table 2 presents the regression results for testing hypothesis one, which examines the impact of hiring a new CEO on a firm's level of REM. All the models fit well with the adjusted $\mathrm{R}^{2}$ values between $11 \%$ and $49 \%$ (significant at 1\% level). Except for the positive but marginally significant relation with abnormal cash flow (AB_CFO) ( $p$-value $<0.1$ ), CEO succession (SUC) is negatively and significantly related to SUM_REM, AB_PROD, and AB_DISEXP (all p-value $<0.01$ ). The coefficients of SUM_REM, AB_CFO, AB_PROD, and AB_DISEXP 
are $-0.033,0.005,-0.016$, and -0.021 , respectively. According to Roychowdhury (2006), the positive relation between SUC and AB_CFO may be induced by the mixed effects of various real earnings manipulation methods on the level of cash flow from operations. The negative relations between CEO succession and most REM proxies indicate that incoming CEOs are less likely to manipulate earnings in ways that impact real operating activities.

With regard to the control variables, the coefficients of DA are positive and significant for all REM proxies, implying that managers may use both AEM and REM at the same time. All coefficients of MB and ROA are negative and significant for all REM proxies, implying that firms with higher growth rates and better performance may not need to manage earnings in this way. LNAT is negative and significant for AB_CFO, AB_PROD, and AB_DISEXP, but marginally significant for SUM_REM. This result indicates that when firms are larger, they are less likely to engage in REM. LITIGATION is negatively and significantly related to SUM_REM, AB_CFO, and AB_PROD, but positively and significantly related to AB_DISEXP. The results imply that firms in high litigation industries are less likely to manage earnings using either REM or AEM. Consistent with the prior literature, LEV is positively and significantly related to all REM proxies, implying that high leverage firms tend to use REM to avoid debt covenant violations (Roychowdhury 2006; Matsuura 2008). BIG4 is positively related with most REM proxies, indicating that firms audited by one of the Big-Four auditors shift from using AEM to REM. Finally, consistent with the results of the correlation tests, the VIFs for independent variables show that VIFs are all smaller than 2.3, suggesting that multicollinearity is not an issue. We also use the nearest sales to match one non-succession observation for each succession observation, and the results are consistent.

Table 2. Results for the relation between real earnings management and CEO succession at the succession year

\begin{tabular}{|c|c|c|c|c|c|}
\hline \multirow[b]{2}{*}{ Variables } & \multirow{2}{*}{$\begin{array}{l}\text { Predicted } \\
\text { Sign }\end{array}$} & \multicolumn{4}{|c|}{ Dependent Variable $(\mathbf{N}=\mathbf{2 , 3 3 9})$} \\
\hline & & SUM_REM & $\mathrm{AB} \mathrm{CFO}^{1}$ & AB_PROD & AB_DISEXP ${ }^{1}$ \\
\hline Intercept & $?$ & $\begin{array}{l}-0.001 \\
(-0.02)\end{array}$ & $\begin{array}{l}0.009 \\
(0.91)\end{array}$ & $\begin{array}{l}0.014 \\
(0.75)\end{array}$ & $\begin{array}{l}-0.024 \\
(-1.12)\end{array}$ \\
\hline SUC & $?$ & $\begin{array}{l}-\mathbf{0 . 0 3 3} * * * \\
(-3.07)\end{array}$ & $\begin{array}{l}0.005 * \\
(1.88)\end{array}$ & $\begin{array}{l}-\mathbf{0 . 0 1 6} * * * \\
(-3.02)\end{array}$ & $\begin{array}{l}-0.021 * * * \\
(-3.29)\end{array}$ \\
\hline DA & + & $\begin{array}{l}1.581 * * * \\
(14.61)\end{array}$ & $\begin{array}{l}0.773 * * * \\
(25.74)\end{array}$ & $\begin{array}{l}0.539 * * * \\
(9.55)\end{array}$ & $\begin{array}{l}0.270 * * * \\
(4.15)\end{array}$ \\
\hline LNAT & $?$ & $\begin{array}{c}-0.007 * \\
(-1.75)\end{array}$ & $\begin{array}{l}-0.010 * * * \\
(-9.46)\end{array}$ & $\begin{array}{l}-0.008 * * * \\
(-3.73)\end{array}$ & $\begin{array}{l}0.011 * * * \\
(4.65)\end{array}$ \\
\hline MB & $?$ & $\begin{array}{l}-0.042 * * * \\
(-16.95)\end{array}$ & $\begin{array}{l}-0.006 * * * \\
(-8.55)\end{array}$ & $\begin{array}{l}-0.020 * * * \\
(-15.18)\end{array}$ & $\begin{array}{l}-0.017 * * * \\
(-10.34)\end{array}$ \\
\hline $\mathrm{ROA}$ & $?$ & $\begin{array}{l}-0.137 * * * \\
(-2.58)\end{array}$ & $\begin{array}{l}-0.188 * * * \\
(-10.10)\end{array}$ & $\begin{array}{l}-0.108 * * * \\
(-3.60)\end{array}$ & $\begin{array}{l}0.159 * * * \\
(4.46)\end{array}$ \\
\hline LEV & + & $\begin{array}{l}0.392 * * * \\
(12.63) \\
\end{array}$ & $\begin{array}{l}0.110 * * * \\
(12.5)\end{array}$ & $\begin{array}{l}0.180 * * * \\
(11.25) \\
\end{array}$ & $\begin{array}{l}0.102 * * * \\
(5.18)\end{array}$ \\
\hline BIG4 & + & $\begin{array}{c}0.016 \\
(0.79)\end{array}$ & $\begin{array}{l}0.012 * * \\
(2.12)\end{array}$ & $\begin{array}{l}0.015^{*} \\
(1.44)\end{array}$ & $\begin{array}{l}-0.011 \\
(-0.85)\end{array}$ \\
\hline LITIGATION & + & $\begin{array}{l}-0.056 * * * \\
(-4.39) \\
\end{array}$ & $\begin{array}{l}-0.026 * * * \\
(-7.29) \\
\end{array}$ & $\begin{array}{l}-0.049 * * * \\
(-7.19)\end{array}$ & $\begin{array}{l}0.019 * * * \\
(2.40)\end{array}$ \\
\hline Year Dummy & & Yes & Yes & Yes & Yes \\
\hline Model F value & & $61.21 * * *$ & $132.08 * * *$ & $48.50 * * *$ & $18.26 * * *$ \\
\hline Adj. $R^{2}$ & & $30.45 \%$ & $48.80 \%$ & $25.67 \%$ & $11.15 \%$ \\
\hline
\end{tabular}


The abnormal levels of cash flow from operations and discretionary expenditures are multiplied by -1 , so that higher values of these suggest higher degrees of REM. ${ }^{2} *, * *, * * *$ denote significance at the $0.10,0.05$, and 0.01 levels, respectively (a one-tailed test for the coefficients with predicted signs, and a two-tailed test otherwise). ${ }^{3}$ An analysis of the Variance Inflationary Factors (VIFs) for each model reveals that VIFs are all smaller than 2.3, suggesting that multicollinearity is not an issue. ${ }^{4}$ Variable definitions are shown in Table 1.

4.2.2 Results for the Relation between Real Earnings Management and the Market Reaction on CEO Succession (H2)

Table 3 shows the results of the tests of hypothesis two. The explanatory powers of the models are all significant at a level of $1 \%$, with adjusted $\mathrm{R}^{2}$ values between $10 \%$ and $53 \%$. In Panel A, it shows the results for the aggregated value of three individual REM variables (SUM_REM). We first use Equation (2) to examine the relationship between CAR and SUM_REM. The coefficient on CAR in the full sample is negative (-0.398) and significant at the $1 \%$ level, suggesting that the new CEO who face greater pressure from the market (negative market reaction) are more likely to engage in REM. Next, we further divide CAR into two groups: positive CAR $(\mathrm{CAR}>0)$ and negative $\mathrm{CAR}(\mathrm{CAR}<0)$. Since $\mathrm{CAR} *$ in these two subgroups proxies the absolute value of CAR, firms with positive coefficients of CAR* indicate that firms are more likely to undertake real activities management. In column 2, the coefficient for the absolute value of negative CAR is positive (0.430) and significant at the $5 \%$ level. Conversely, in column 3, the coefficient for the absolute value of positive CAR is negative (-0.769) and significant at the 1\% level. By using Wald Coefficient Test to analyze the coefficient difference of CAR* between these two sub-samples, the result shows that CEO succession firms with negative CAR are more likely to engage in REM, as measured by SUM_REM, than CEO succession firms with positive CAR, significant at the $1 \%$ level (F-value=3.66). These results thus support hypothesis two.

Similarly, panel B to D of Table 3 shows the results for three separate proxies of REM. For brevity, we only summarize the results about the main variable. The results show that the coefficient of CAR in the full sample is negatively and significantly ( $p$-value $<0.05$ at least) related to overproduction (AB_PROD) and abnormal discretionary expenditures (AB_DISEXP). Most coefficients of $\mathrm{CAR}^{*}$ for the $\mathrm{CAR}<0$ group (CAR $>0$ group) are significant and positive (negative). And the Wald Coefficient Test to examine the differences in coefficients between these two groups shows that CEO succession firms with negative CAR are more likely to engage in REM, as measured by AB_CFO, AB_PROD, and AB_DISEXP, than those with positive CAR. Hypothesis two is also supported by these findings. Finally, the results regarding to control variables in Table 3 are qualitatively the same as those reported in Table 2. 
Table 3. Results for the level of real earnings management at the succession year

\begin{tabular}{|c|c|c|c|c|c|}
\hline \multicolumn{6}{|c|}{ Panel A: The Results for the Aggregation of Real Earnings Management } \\
\hline \multirow[b]{3}{*}{ Variables } & \multirow{3}{*}{$\begin{array}{l}\text { Predicted } \\
\text { Sign }\end{array}$} & \multicolumn{4}{|c|}{ Dependent Variable: SUM_REM } \\
\hline & & \multirow[b]{2}{*}{ Full Sample } & \multicolumn{2}{|c|}{ Sub Sample } & \multirow{2}{*}{$\begin{array}{l}\text { Difference in Coef. } \\
\text { (Wald test } F \text { value) }\end{array}$} \\
\hline & & & $\mathrm{CAR}<0$ & $\mathrm{CAR}>0$ & \\
\hline Intercept & $?$ & $\begin{array}{l}-0.103 * * \\
(-2.09)\end{array}$ & $\begin{array}{l}-0.050 \\
(-0.68)\end{array}$ & $\begin{array}{c}-0.141 * \\
(-1.79)\end{array}$ & $\begin{array}{l}0.091 \\
(0.85)\end{array}$ \\
\hline CAR & - & $\begin{array}{l}-0.398 * * * \\
(-3.15)\end{array}$ & & & \\
\hline CAR* & + & & $\begin{array}{l}\mathbf{0 . 4 3 0} * * \\
(2.08)\end{array}$ & $\begin{array}{l}-0.769 * * * \\
(-3.03)\end{array}$ & $\begin{array}{l}1.199 * * * \\
(3.66)\end{array}$ \\
\hline DA & + & $\begin{array}{l}1.572 * * * \\
(10.45)\end{array}$ & $\begin{array}{l}1.855 * * * \\
(8.35)\end{array}$ & $\begin{array}{l}1.334 * * * \\
(5.73)\end{array}$ & $\begin{array}{l}0.521 \\
(1.62)\end{array}$ \\
\hline LNAT & $?$ & $\begin{array}{l}0.002 \\
(0.29)\end{array}$ & $\begin{array}{l}0.002 \\
(0.23)\end{array}$ & $\begin{array}{l}-0.001 \\
(-0.12)\end{array}$ & $\begin{array}{l}0.003 \\
(0.24)\end{array}$ \\
\hline MB & $?$ & $\begin{array}{l}-0.040 * * * \\
(-12.96)\end{array}$ & $\begin{array}{l}-0.043 * * * \\
(-8.80)\end{array}$ & $\begin{array}{l}-0.038 * * * \\
(-8.42)\end{array}$ & $\begin{array}{l}-0.005 \\
(-0.81)\end{array}$ \\
\hline ROA & $?$ & $\begin{array}{l}-0.203 * * * \\
(-3.04)\end{array}$ & $\begin{array}{l}-0.202 * * \\
(-2.10)\end{array}$ & $\begin{array}{l}-0.219 * * \\
(-2.07)\end{array}$ & $\begin{array}{l}0.017 \\
(0.12)\end{array}$ \\
\hline LEV & + & $\begin{array}{l}0.371 * * * \\
(7.65)\end{array}$ & $\begin{array}{l}0.312 * * * \\
(4.84)\end{array}$ & $\begin{array}{l}0.448 * * * \\
(6.48)\end{array}$ & $\begin{array}{l}-0.136 \\
(-1.44)\end{array}$ \\
\hline BIG4 & + & $\begin{array}{l}0.035 \\
(1.20)\end{array}$ & $\begin{array}{l}0.040 \\
(1.11)\end{array}$ & $\begin{array}{l}0.030 \\
(0.63)\end{array}$ & $\begin{array}{l}0.010 \\
(0.17)\end{array}$ \\
\hline LITIGATION & + & $\begin{array}{l}-0.066 * * * \\
(-3.65)\end{array}$ & $\begin{array}{l}-0.053 * * \\
(-2.13)\end{array}$ & $\begin{array}{l}-0.076 * * * \\
(-2.89)\end{array}$ & $\begin{array}{l}0.023 \\
(0.66)\end{array}$ \\
\hline $\mathrm{N}$ & & 1,178 & 582 & 596 & \\
\hline Year Dummy & & Yes & Yes & Yes & \\
\hline Model F value & & $28.29 * * *$ & $16.16 * * *$ & $13.83 * * *$ & \\
\hline Adj. $\mathrm{R}^{2}$ & & $28.27 \%$ & $30.72 \%$ & $26.82 \%$ & \\
\hline \multicolumn{6}{|c|}{ Panel B: The Results for Abnormal Levels of Cash Flow from Operations ${ }^{I}$} \\
\hline CAR & - & $\begin{array}{l}-0.020 \\
(-0.64)\end{array}$ & & & \\
\hline CAR* & + & & $\begin{array}{l}0.144 * * * \\
(2.65)\end{array}$ & $\begin{array}{c}-0.041 \\
(-0.76)\end{array}$ & $\begin{array}{l}\mathbf{0 . 1 8 5 * * *} \\
(2.42)\end{array}$ \\
\hline \multicolumn{6}{|c|}{ Panel C: The Results for Abnormal Levels of Production Costs } \\
\hline CAR & - & $\begin{array}{l}-0.200 * * * \\
(-3.23)\end{array}$ & & & \\
\hline CAR* & + & & $\begin{array}{l}0.245 * * \\
(2.28)\end{array}$ & $\begin{array}{l}-0.428 * * * \\
(-3.66)\end{array}$ & $\begin{array}{l}0.673 * * * \\
(4.24)\end{array}$ \\
\hline \multicolumn{6}{|c|}{ Panel D: The Results for Abnormal Levels of Discretionary Expenses ${ }^{I}$} \\
\hline CAR & - & $\begin{array}{l}-0.179 * * \\
(-2.28)\end{array}$ & & & \\
\hline CAR* & + & & $\begin{array}{l}0.041 \\
(0.29)\end{array}$ & $\begin{array}{l}-0.300 * * \\
(-1.90)\end{array}$ & $\begin{array}{l}0.341 * \\
(1.62)\end{array}$ \\
\hline $\begin{array}{l}\text { The abnormal } \\
\text { these suggest his } \\
\text { test for the coef } \\
\text { (VIF) for each } \\
\text { absolute value o }\end{array}$ & $\begin{array}{l}\text { cash flow } \\
\text { ees of REI } \\
\text { ith a pred } \\
\text { eals that }\end{array}$ & $\begin{array}{l}\text { perations and } \\
k *, * * * \text { denote } \\
\text { gn, and a two } \\
\text { re all smaller }\end{array}$ & $\begin{array}{l}\text { nary expendit } \\
\text { ance at the } 0.1 \\
\text { st otherwise). } \\
\text { suggesting } t\end{array}$ & $\begin{array}{l}\text { are multiplied } \\
05 \text {, and } 0.011 \\
\text { analysis of th } \\
\text { nulticollinearit }\end{array}$ & $\begin{array}{l}\text { so that higher values } \\
\text { espectively (a one-tail } \\
\text { ince Inflationary Facto } \\
\text { ot an issue. }{ }^{4} \mathrm{CAR}^{*} \text { : th }\end{array}$ \\
\hline
\end{tabular}

\subsection{Additional Tests-Results Investigated by Change Models}

In order to exclude the possibility that firms may engage in REM no matter whether they replace their CEOs or not, we conduct the change model of Equation (1) to examine hypothesis one again (Geiger and North 2006). We also conduct the change model of Equation (2) to examine hypothesis two to control for any potential selection bias (e.g. 
Carcello et al. 2010). That is, to control for the possibility that a CEO with a better public reputation may choose to work at firms with good financial reporting quality. Referring to Geiger and North (2006), we include REM at t-1 in the change models since firms may manage earnings continuously. Table 4 shows the related results. Similar to the results in Tables 2, from the period immediately prior to the succession ( $t-1)$ to the new CEO succession ( $\mathrm{t}$ ), firms with new CEOs (SUC) are negatively and significantly associated with most REM proxies, except for the marginally significant relation with $\triangle \mathrm{AB} \_\mathrm{CFO}$. Regarding hypothesis two, CAR in the full sample is still negatively and significantly related with most REM proxies. Using the change model with the subsamples, we test the differences between the positive and negative CAR groups. Consistent with Tables 3, most of the results indicate that in order to improve market perceptions of their performance and establish better reputations, new CEOs with negative CAR on their succession are more likely to engage in REM than those with positive CAR on their succession. Briefly, hypothesis one and two are thus supported by the change model analyses.

Table 4. Results for the change models

\begin{tabular}{|c|c|c|c|c|}
\hline \multicolumn{5}{|c|}{ Panel A: The Results for $H 1(\mathrm{~N}=2,223)$} \\
\hline \multirow[b]{2}{*}{ Variables } & \multicolumn{4}{|c|}{ Dependent Variable } \\
\hline & $\triangle$ SUM_REM & $\triangle \mathrm{AB} \_\mathrm{CFO}$ & $\triangle \mathrm{AB} P \mathrm{PROD}$ & $\triangle \mathrm{AB}$ DISEXP \\
\hline \multirow[t]{2}{*}{ SUC } & $-0.022 * * *$ & $-0.003 *$ & $-0.009 * * *$ & $\mathbf{- 0 . 0 1 0} * * *$ \\
\hline & $(-3.97)$ & $(-1.64)$ & $(-3.03)$ & $(-3.03)$ \\
\hline \multicolumn{5}{|c|}{ Panel B: The Results for H2-Full sample $(\mathrm{N}=1,137)$} \\
\hline \multirow[t]{2}{*}{ CAR } & $-0.149 * * *$ & -0.011 & $-0.074 * *$ & $-0.062 * *$ \\
\hline & $(-2.53)$ & $(-\mathbf{0 . 5 0})$ & $(-2.24)$ & $(-1.91)$ \\
\hline \multicolumn{5}{|c|}{ Panel C: The Results for H2-The difference between two subsamples $(\mathrm{N}=1,137)$} \\
\hline \multirow[b]{2}{*}{ CAR* } & & fference in $\mathrm{Cc}$ & ald test $F$ value & \\
\hline & $\begin{array}{l}0.345 * * \\
(2.27)\end{array}$ & $\begin{array}{l}0.065 \\
(1.14)\end{array}$ & $\begin{array}{l}0.226 * * * \\
(2.66)\end{array}$ & $\begin{array}{c}0.055 \\
(0.65)\end{array}$ \\
\hline \multicolumn{5}{|c|}{$\begin{array}{l}1 * * *, * * * \text { denote significance at the } 0.10,0.05 \text {, and } 0.01 \text { levels, respectively (a one-tailed test for the coefficients } \\
\text { with a predicted sign, and a two-tailed test otherwise). }{ }^{2} \text { An analysis of the Variance Inflationary Factors (VIFs) for } \\
\text { each model reveals that VIFs are all smaller than } 3.0 \text {, suggesting that multicollinearity is not an issue. }{ }^{3} \Delta \mathrm{AB} C \mathrm{CFO} \\
\text { The change in the abnormal level of cash flow from operations; } \triangle \mathrm{AB} \text { PROD: The change in the abnormal level of } \\
\text { production costs; } \triangle \mathrm{AB} \text { DISEXP: The change in the abnormal level of discretionary expenditures; } \Delta \mathrm{SUM} \text { REM: The } \\
\text { aggregation of } \triangle \mathrm{AB} \text { CFFO, } \triangle \mathrm{AB} \text { PROD, and } \triangle \mathrm{AB} \text { DISEXP; other variable definitions are shown in Table } 1 .\end{array}$} \\
\hline
\end{tabular}

\section{Conclusion}

During the past decade average CEO tenure has rapidly become shorter, and markets may react more negatively when there is greater uncertainty with regard to future performance because of this. The prior literature finds that new CEOs are more likely to engage in discretionary accruals earnings management, a fact that is explained by the idea of "taking a big bath" or impression management theory. Due to the greater litigation risk in the post-SOX period, firms are now more likely to manipulate earnings by REM instead of discretionary accruals earnings management. Different to AEM, REM is an earnings management approach that influences a firm's cash flows and future performance, which is a concern may impact 
the decisions of new CEOs with regard to manipulating earnings. Therefore, our research is to investigate the relation between CEO succession and REM in the post-SOX era and whether market reaction on CEO succession can motivate the new CEO to engage in REM for reputation and career concern.

Our findings indicate that the incoming CEO is less likely to manipulate real activities for earnings management in their first year of employment, but if they are faced with lower market expectations $(\mathrm{CAR}<0)$ on succession, then the new CEO tends to engage in REM in order to boost current earnings and enhance how the market sees their abilities. Our empirical results remain unchanged when the test is examined by change models. Overall, we provide a new perspective with regard to market reactions to CEO successions, by examining how and why new CEOs may choose to manipulates earnings.

\section{References}

Ali A., \& Zhang, W. (2013). CEO Tenure and Earnings Quality. Working paper, University of Texas at Dallas. http://dx.doi.org/10.2139/ssrn.2060119

Aono, J. Y., \& Guan, L. (2007). The impact of Sarbanes-Oxley act on cosmetic earnings management. Research in Accounting Regulation, 20, 205-215. http://dx.doi.org/10.1016/S1052-0457(07)00212-3

Bartov, E., Givoly, D., \& Hayn, C. (2002). The rewards to meeting or beating analysts' forecasts. Journal of Accounting and Economics, 33, 173-204. http://dx.doi.org/10.1016/S0165-4101(02)00045-9

Beatty, R. P., \& Zajac, E. J. (1987). CEO change and firm performance in large corporations: Succession effects and manager effects. Strategic Management Journal, 8, 305-317. http://dx.doi.org/10.1002/smj.4250080402/abstract

Beaver, W. (1968). The information content of annual earnings announcements. Journal of Accounting Research, Supplement, 67-92. http://dx.doi.org/10.1016/j.jacceco.2011.04.002

Bhojraj, S., \& Libby, R. (2005). Capital market pressure, disclosure frequency-induced earnings/cash flow conflict, and managerial myopia. The Accounting Review, 80, 1-20. http://dx.doi.org/10.2308/accr.2005.80.1.1

Brown, S. J., \& Warner, J. B. (1980). Measuring security price performance. Journal of Financial Economics, 8, 205-258. http://dx.doi.org/10.1016/0304-405X(80)90002-1

Burgstahler, D., \& Dichev, I. (1997). Earnings management to avoid earnings decreases and losses. Journal of Accounting and Economics, 24, 99-126. http://dx.doi.org/10.1016/S0165-4101(97)00017-7

Cao, Y., Myers, L. A., \& Omer, T. C. (2012). Does company reputation matter for financial reporting quality? Evidence from Restatements. Contemporary Accounting Research, 29(3), 956-990. http://dx.doi.org/10.1111/j.1911-3846.2011.01137.x

Carcello, J. V., Hollingsworth, C. W., Klein, A., \& Neal, T. L. (2010). The Role of Audit 
Committee Financial Experts in the Post-Sox Era: Have Smaller Public Companies Benefited Disproportionately? Working paper, The University of Tennessee.

Chi, W., Lisic, L. L., \& Pevzner, M. (2011). Is enhanced audit quality associated with greater real earnings management? Accounting Horizons, 25(2), 315-335. http://dx.doi.org/10.2308/acch-10025

Clayton, M., Hartzell, J., \& Rosenberg, J. (2005). The impact of CEO turnover on equity volatility. Journal of Business, 78, 1779-1808. http://dx.doi.org/10.1086/431442

Cohen, D., Dey, A., \& Lys, T. (2008). Real and accrual-based earnings management in the pre- and post-Sarbanes Oxley period. The Accounting Review, 83(3), 757-787. http://dx.doi.org/10.2308/accr.2008.83.3.757

Cohen, D. A., \& Zarowin, P. (2010). Accrual-based and real earnings management activities around seasoned equity offerings. Journal of Accounting and Economics, 50, 2-19. http://dx.doi.org/10.1016/j.jacceco.2010.01.002

Davidson III, Jiraporn, W. P., Kim, Y. S., \& Nemec, C. (2004). Earnings management follow- ing duality-creating successions: Ethnostatistics, impression management, and agency theory. Academic of Management Journal, 47, 267-275. http://dx.doi.org/10.2307/20159577

Dechow, P. M., Kothari, S. P., \& Watts, R. L. (1998). The relation between earnings and cash flows. Journal of Accounting and Economics, 25(2), 133-168. http://dx.doi.org/10.1016/S0165-4101(98)00020-2

Demerjian, P., Lev, B., \& McVay, S. (2012). Quantifying managerial ability: A new measure

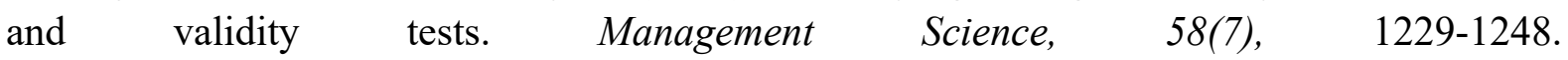
http://dx.doi.org/10.1287/mnsc.1110.1487

Francis, J., Huang, A. H., Rajgopal, S., \& Zang, A. Y. (2008). CEO reputation and earnings quality. Contemporary Accounting Research, 25, 109-147. http://dx.doi.org/10.1506/car.25.1.4

Furtado, E. P. H., \& Karan, V. (1990). Causes, consequences, and shareholder wealth effects of management turnover: A review of the empirical evidence. Financial Management, 19, $60-75$.

Geiger, M. A., \& North, D. S. (2006). Does hiring a new CFO change things? An investigation of changes in discretionary accruals. The Accounting Review, 81, 781-809. http://dx.doi.org/10.2308/accr.2006.81.4.781

Godfrey, J., Mather, P., \& Ramsay, A. (2003). Earnings and impression management in finan- cial reports: The case of CEO changes. ABACUS, 39, 95-123. http://dx.doi.org/10.1111/1467-6281.00122

Graham, J., Harvey, C., \& Rajgopal, S. (2005). The economic implications of corporate financial reporting. Journal of Accounting and Economics, 40, 3-73. http://dx.doi.org/10.1016/j.jacceco.2005.01.002 
Gunny, K. A. (2010). The relation between earnings management using real activities manipulation and future performance: Evidence from meeting earnings benchmarks. Contemporary Accounting Research, 855-888. http://dx.doi.org/ 10.1111/j.1911-3846.2010.01029.x

Healy, P. M., \& Wahlen, J. M. (1999). A review of the earnings management literature and its implications for standard setting. Accounting Horizons, 13, 365-383. http://dx.doi.org/10.2308/acch.1999.13.4.365

Holmstrom, B. (1999). Managerial incentive problems: a dynamic perspective. Review of Economic Studies, 66, 183-98. http://dx.doi.org/10.1111/1467-937X.00083

Huson, M. R., Malatesta, P. H., \& Parrino, R. (2004). Managerial succession and firm performance. Journal of Financial Economics, 74, 273-275. http://dx.doi.org/10.1016/j.jfineco.2003.08.002

Johnson, E. N., Fleischman, G. M., Valentine, S., \& Walker, K. B. (2012). Managers' ethical evaluations of earnings management and its consequences. Contemporary Accounting Research, 29(3), 910-927. http://dx.doi.org/10.1111/j.1911-3846.2011.01135.x

Jones, J. (1991). Earnings management during import relief investigations. Journal of Accounting Research, Autumn, 193-228.

Knous, S. B., \& Giacalone, R. A. (1992). Ethical decision-making in business: behavioral issues and concerns. Journal of Business Ethics, 11, 369-377. http://dx.doi.org/10.1007/BF00870549

Kothari, S. P., Leone, A. J., \& Wasley, C. E. (2005). Performance matched discretionary accrual measures. Journal of Accounting and Economics, 39(1), 163-197. http://dx.doi.org/10.1016/j.jacceco.2004.11.002

Matsuura, S. (2008). On the relation between real earnings management and accounting earnings management: Income smoothing perspective. Journal of International Business Research, 7(3), 63-77.

Milbourn, T. (2003). CEO reputation and stock-based compensation. Journal of Financial Economics, 68, 233-262. http://dx.doi.org/10.1016/S0304-405X(03)00066-7

Pourciau, S. (1993). Earnings management and nonroutine executive changes. Journal of Accounting and Economics, 16, 317-336. http://dx.doi.org/10.1016/0165-4101(93)90015-8

Roychowdhury, S. (2006). Earnings management through real activities manipulation. Journal of Accounting and Economics, 42, 335-370. http://dx.doi.org/10.1016/j.jacceco.2006.01.002

Seybert, N. (2010). R\&D capitalization and reputation-driven real earnings management. The Accounting Review, 85, 671-693. http://dx.doi.org/10.2308/accr.2010.85.2.671

Taylor, G. K., \& Xu, R. Z. (2010). Consequences of real earnings management on subsequent operating performance. Research in Accounting Regulation, 22, 128-132. 
http://dx.doi.org/10.1016/j.racreg.2010.07.008 2015, Vol. 7, No. 2

Warner, J. B., Watts, R. L., \& Wruck, K. H. (1988). Stock prices and top management changes. Journal of Financial Economics, March, 461-492. http://dx.doi.org/10.1016/0304-405X(88)90054-2

Zang, A. (2012). Evidence on the tradeoff between real activities manipulation and accrual-based earnings management. The Accounting Review, 87(2), 675-703. http://dx.doi.org/10.2308/accr-10196

Zhao, Y., Chen, K. H., Zhang, Y., \& Davis, M. (2012). Takeover protection and managerial myopia: Evidence from real earnings management. Journal of Accounting and Public Policy, 31, 109-135. http://dx.doi.org/10.1016/j.jaccpubpol.2011.08.004

Zhou, J. (2007). Financial reporting after the Sarbanes-Oxley Act: Conservative or less earnings management? Research in Accounting Regulation, 20, 187-192. http://dx.doi.org/10.1016/S1052-0457(07)00210-X 